\title{
単独樹木周辺の気流解析に関する研究 \\ A STUDY ON ANALYSIS OF AIRFLOW AROUND AN INDIVIDUAL TREE
}

\author{
大橋 征 幹* \\ Masamiki OHASHI
}

\begin{abstract}
The purpose of this study is to predict the influence of trees on airflow around buildings by using CFD. In order to analyze the airflow around and through trees, the modeling of the aerodynamic effect of trees is required. Many plant canopy turbulence models have been developed in the past study of dendrology and agricultural meteorology. Almost all the models, however, were examined under horizontally homogeneous conditions. Using one- or two-dimensional computational domains, they have been developed for plant fields (e.g. corn fields, coniferous forests). In this study, airflow caused by an individual tree is estimated through three-dimensional calculations on these above models. The calculated airflow, compared with results of the wind-tunnel experiment, shows usefulness and limitations of the models, allowing for improvement of the model for analysis of airflow around an individual tree.
\end{abstract}

Keywords: CFD, Turbulence model, Tree, Canopy, Wind-tunnel experiment 数値流体力学, 乱流モデル, 樹木, キャノピー, 風洞実験

\section{1.はじめに}

身近な自然環境の代表である緑は、安全で快適な居住環境を創り 出すための道具として様々な目的で活用されている。

樹木は風の調節に対して適した特徵を持っている。樹木を計画的 に配置することによって、建物周辺の風環境を調節することができ る。樹木は防風林やビル風問題の対策として用いられるように風速 低隇効果を期待されることが多く、既往の研究 ${ }^{2)}$ 〜) では、見付面 積とその遮蔽率によって樹木の形状が表現され、実験的にその効果 が明らかにされてきた。しかし、樹木の影響をモデル表現すること により、建物と樹木の組み合わせにより形成される風環境を数值計 算によって予測することが可能となる。樹木の気流に対する性状の モデル化については森林や農業気象の分野を中心に植物キャノピー 層を対象とした乱流モデルの研究がある。植物キャノピー乱流モデ ルでは一般に抵抗係数を決める際の代表面積として葉面積密度を用 いる。樹種の違いは抵抗係数と葉面積密度の分布により表現される。 主に畑や森林などを対象とするこれらの研究では、対象とする場を 水平方向に一様とみなし、その多くがl次元で検討されてきた。そ のため、葉面積密度は高さ方向に分布を持った 1 次元のプロファイ ルで与えられる。乱流モデルとしては 2 次元、3 次元の対応を検討 されている場合でも、キャノピー層を対象としているため計算領域
の形状はほとんどが2次元以下に設定されている。 一方、建物周辺気流の解析において建物近傍に配置される単独の 樹木を建物と同レベルで表現するためには、その樹冠内部の立体的 な構造を明らかにし、葉面積密度の 3 次元空間分布を把握する必要 がある。植物キャノピー層を対象とした研究では、このように細か く不連続な 3 次元的分布を持つ葉面積密度を与えた場合の検討はな されておらず、単独樹木を対象とした場合のモデルの有効性も十分 な確認がされていない。

本研究では、建物周辺の風環境に対する樹木の影響を数値シミュ レーションによって検討することを可能とするために、樹木の風に 対する抵抗のモデル表現について検討する。森林や畑を対象に開発 されている植物キャノピー乱流モデルを、独立した単独の樹木に用 いた場合の有効性を検証し、これまでに提案されている種々のモデ ルの特徴を明らかにする。また、これらのモデルの改良点について 検討を加え、単独の樹木に適したモデルを提案する。

\section{2. 風洞実験}

実物の樹木を用いた風洞実験を行い、モデル比較・検証ためのデー 夕を取得した。実験に用いる樹種はサザンカとし、高さ約 $1.2 \mathrm{~m} の$ 低木の頂部付近の枝を直径 $10 \mathrm{~mm}$ のアルミ製支柱に固定して試験 


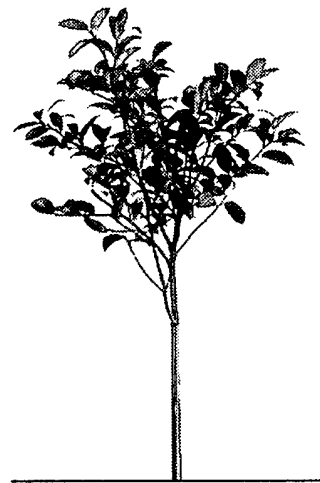

正面 (y-z)

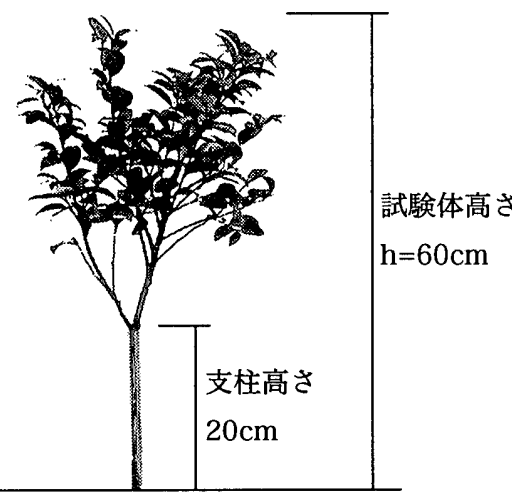

側面 (x-z)

図 1 試験体（サザンカ）

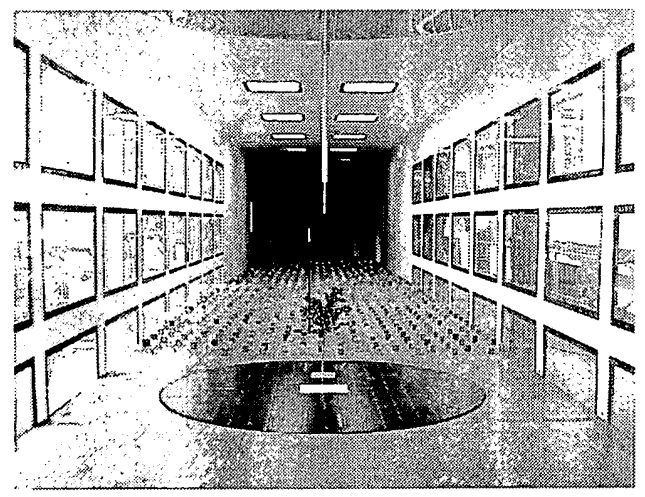

図 2 風洞内の設圈状況

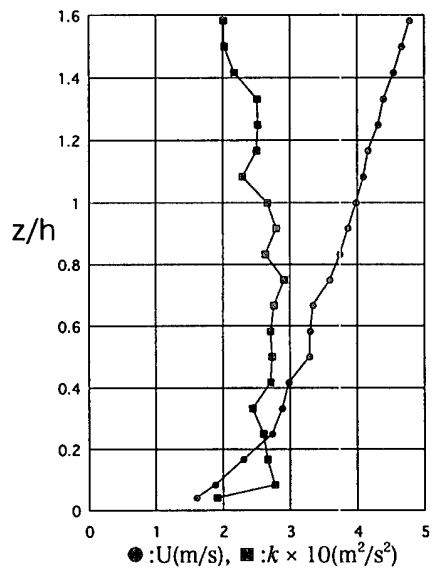

図 3 流入プロファイル

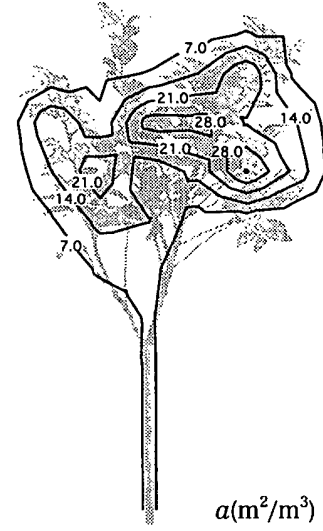

图 5 葉面皘密度分布

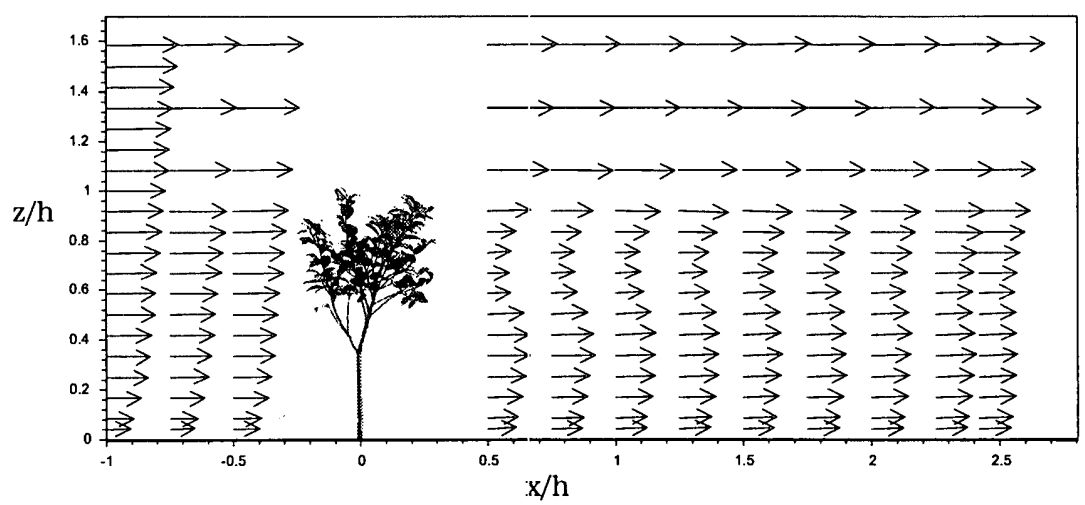

図 4 汗均風速分布

体を作成した。（図 1)

実験に使用した風洞（図 2 : 建築研究所乱流境界層風洞）の断面 は幅 $3.0 \mathrm{~m}$ 高さ $2.5 \mathrm{~m}$ であり、スパイアーとラフネスブロック（高 さ $5 \mathrm{~cm})$ により基準高さ $\mathrm{h}$ (=試験体高さ $0.6 \mathrm{~m})$ で約 $15 \%$ の乱 れ強さを持つ流入プロファイルを作成した（図 3 )。スパイアーか ら試験体までの距離は $15 \mathrm{~m}$ である。風洞内の座標系は、主流方向

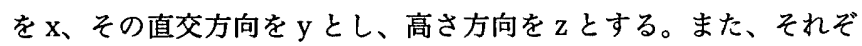

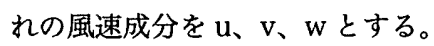

風速の測定には、X型熱線流速計（Dantec 55P61）を用い、サ ンプリング周波数 $1 \mathrm{kHz}$ で 30 秒間測定し平均風速を求めた。また、 プローブを 90 度回転し $\mathrm{u}, \mathrm{v}$ 成分と $\mathrm{u}, \mathrm{w}$ 成分の 2 回に分けて測定す ることによって、各成分の乱れを計測した。

風速の測定点は、樹木中心 $\left(\mathrm{y}_{0}: \mathrm{y}=0\right)$ を通る $\mathrm{x}-\mathrm{z}$ 断面上の 185 点 を設定した。測定した平均風速べクトルを図 4 に示す。

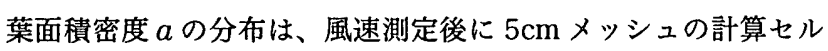
単位で葉を刈り取って測定した。葉面積には葉のみでなく枝の部分 もその表面積の $1 / 2$ を含めた。風速測定断面の $a$ の分布を図 5 に 示す。

\section{3. 植物キャノピー乱流モテル}

植物キャノピー気流の数值計算は、Wilson, N.R. \& Shaw, R.H. ${ }^{5)}$ や Raupach, M.R. \& Shaw, R.H. ${ }^{6)}$ 、Yamada, T. ${ }^{7)}$ などの多方程式 モデルによる検討により本格的な研究が行われるようになってき た。

平岡ら ${ }^{8)}$ は、植物群落や都市の建物群を対象とした 3 次元乱流
モデルを開発し $k-\varepsilon$ モデルと応力方程式モデルで示した。平岡ら の $k-\varepsilon$ モデルでは、 $\varepsilon$ 烒に与える抵抗物体（建物や樹木）による乱 れへの影響が、aの関数で与えられている。これは、従来植物乱流 モデルで一般的に用いられてきた $k$ 収支の局所平衡の仮定によるモ デルと大きく異なる。平岡ら ${ }^{9)}$ は、Shaw, R.H. et al. ${ }^{10)}$ の実験及 び Wilson, J.D. ${ }^{(1)}$ の奏験データとの比較によりこのモデルの有効 性を示した。

Uno, I. et al. ${ }^{12)}$ は、Yamada, T.の $k-k l$ モデルを $k-\varepsilon$ モデルに 変換して都市キャノピー層の解析を行った。また、Svensson, U. \& Häggkvist, K. ${ }^{13)}$ も、Uno, I. et al. と同様のモデルを提案している。 Green, S.R. ${ }^{14)}$ は、Wilson, J.D. を元にキャノピー内部における 特異なエネルギー収支の過程を考慮し、葉による乱れの消散項を加 えたモデルを提案した。Green, S.R.は、このモデルにより2次元 計算を行い、森林模型による風洞実験とよく一致することを確認し た。

Liu, J. et al. ${ }^{15)}$ は、森林の微気象を予測する目的で Green, S.R. のモデルを用いて林縁部の 2 次元シミュレーションを行った。Liu, J. et al.は模型による実験データとの比較により Green, S.R.の式 の係数を補正した。

\section{4. モテル基礎式}

標準 $k-\varepsilon$ モデルをベースに前述の植物キャノピー乱流モデルの基 礎式を表 1 にまとめ、各モデルについてその違いを示す。なお、平 岡らは抵抗物体の体積変化を考慮して有効体積率を与えているが、 ここでは、伎葉による体積変化は少ないとみなしこれを無視する。 
また、改良モデルについては後述する。

樹木に働く力は抗力のみを考え、抵抗係数 $C_{f}$ の代表面積を $a$ と すると葉群による単位体積あたりの抗力 $F_{i}$ は（10）式で表される。 平均流の式にこの抗力項を加え、（5）式が得られる。

$k$ の輸送方程式は、各モデルを（6）式のようにまとめることが できる。表中の係数については、それぞれのモデルに応じた值が与 えられる。また、平岡らの式のみ乱流抎散項に補正係数 $C_{r r}$ が与え られる。Green, S.R.の式には葉の影響が乱れのエネルギー収支に 対して生成のほかに消散のために作用するとして $L_{k}$ が追加される。 L は、Green,S.R. と Liu, J. et al.の式に与えられる。

$\varepsilon$ の輸送方程式は $(7)$ 式のように表される。 $F_{\varepsilon}$ は、平岡らの モデルを除いて（6）の式の $F_{k}$ との平衡を仮定して与えられる。

Uno, I. et al.は Yamada, T. のモデルを次の関係式を用いて変 換した。

$$
\frac{\partial \varepsilon}{\partial t}=\frac{3}{2} \frac{\varepsilon}{k} \frac{\partial k}{\partial t}-\frac{\varepsilon}{l} \frac{\partial l}{\partial t}
$$

において、

$$
\frac{\partial l}{\partial t} \approx 0
$$

この仮定により $C_{p I \varepsilon}$ は 1.5 とされる。一方、Svensson, U. \& Hä ggkvist, K. は、実験データとの比較から最適な $C_{p l \varepsilon}$ を 1.95 とした。

Green,S.R.のモデルでは $k$ の式の $L_{k}$ に応じた $L_{\varepsilon}$ が付加される。 Liu et al. はこの $L_{\varepsilon}$ の係数 $C_{p 2 \varepsilon}$ を数値計算の結果から補正している。 平岡らは、村上ら ${ }^{16), 17)}$ のモデル化に従い抵抗物体による $\varepsilon$ の生 成項を次式でモデル化した。

$$
F_{\varepsilon}=\frac{k^{3 / 2}}{L}
$$

ここで葉による渦の特徵長さスケール $L$ については $a$ の逆数で与 えられる。

\section{5. 計算条件}

葉面積密度を代表面積とした場合のサザンカの抵抗係数について

\section{表 $1 \quad k-\varepsilon$ 植物キャノピー乱流モデル基礎式}

$\frac{\partial U_{i}}{\partial x_{i}}=0$
$\frac{\partial U_{i}}{\partial t}+U_{j} \frac{\partial U_{i}}{\partial x_{j}}=-\frac{\partial}{\partial x_{i}}\left(\frac{P}{\rho}+\frac{2}{3} k\right)+\frac{\partial}{\partial x_{i}}\left(\nu_{i}\left(\frac{\partial U_{j}}{\partial x_{i}}+\frac{\partial U_{j}}{\partial x_{i}}\right)\right)-F_{i}$
$\frac{\partial k}{\partial t}+U_{j} \frac{\partial k}{\partial x_{j}}=\frac{\partial}{\partial x_{j}}\left(\frac{\nu_{t}}{\sigma_{t}} C_{r r} \frac{\partial k}{\partial x_{j}}\right)+S-\varepsilon+F_{k}-L_{k}$
$\frac{\partial \varepsilon}{\partial t}+U_{j} \frac{\partial \varepsilon}{\partial x_{j}}=\frac{\partial}{\partial x_{j}}\left(\frac{\nu_{t}}{\sigma_{\varepsilon}} \frac{\partial \varepsilon}{\partial x_{j}}\right)+\frac{\varepsilon}{k}\left(C_{1 \varepsilon} S-C_{2 \varepsilon} \varepsilon+C_{p 1 \varepsilon} F_{\varepsilon}-C_{p 2 \varepsilon} L_{\varepsilon}\right)(7)$
$S=\nu_{i}\left(\frac{\partial U_{i}}{\partial x_{j}}+\frac{\partial U_{j}}{\partial x_{i}}\right) \frac{\partial U_{i}}{\partial x_{j}}$
$V_{t}=C_{D} \frac{k^{2}}{\varepsilon}$
$F_{i}=C_{f} a U_{i} \sqrt{U_{j}^{2}}$
$F_{k}=U_{j} F_{j}$
$L_{k}=4 C_{f} a \sqrt{U_{j}^{2}} k$
$C_{D}=0.09, \sigma_{i}=1.0, \sigma_{\varepsilon}=1.3, C_{1 \varepsilon}=1.44, C_{2 \varepsilon}=1.92$

·今回求めた最適值。平岡らの㭲討では、植物で $0.8 \sim 1.2$ 、都市で 10.0 程度。
は、筆者らの実験 ${ }^{18)}$ により $C_{f}=0.275$ ((10) 式での表記上、 $C_{f} に$ $1 / 2$ を含めた場合）という結果が得られている。ここでは $C_{f}=0.3$ とした。

計算領域を図 6 に示す。メッシュ幅は $\mathrm{x} 、 \mathrm{y} 、 \mathrm{z}$ 方向とも全域で $1 / 12 \mathrm{~h}$ とした。

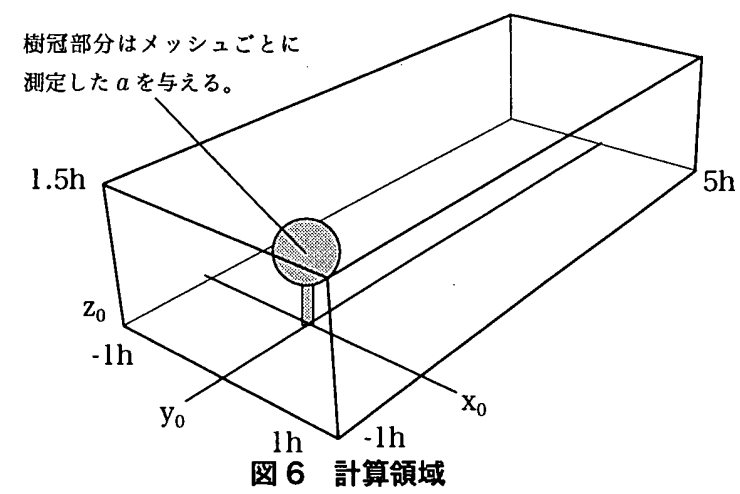

数值解法には ABMAC 法を用いた。空間差分にはQUICK スキー ム、時間差分は Adams-Bashforth スキームを使用した。

\begin{tabular}{|c|c|}
\hline 流入面 & $\begin{array}{l}\mathrm{u}, \mathrm{k}: \text { 実験値の分布を与える。 } \\
\mathrm{v}=0, \mathrm{w}=0 \\
\varepsilon(z)=\frac{C_{D}^{3 / 4} k(z)^{3 / 2}}{\kappa z}\end{array}$ \\
\hline 流出面 & $\mathrm{u}, \mathrm{v}, \mathrm{w}, \mathrm{k}, \varepsilon: \frac{\partial}{\partial x}=0$ \\
\hline 上面 & $\frac{\partial u}{\partial z}=0, v=0, w=0, \frac{\partial k}{\partial z}=0, \frac{\partial \varepsilon}{\partial z}=0$ \\
\hline 本面 & $\begin{array}{l}\mathrm{u}, \mathrm{v}: \text { ベき乗則 } u_{z-1}=(1-2 \alpha) u_{z 1}, \alpha=1 / 4 \\
\frac{\partial k}{\partial z}=0, \varepsilon_{z 1}=\frac{C_{D}^{3 / 4} k_{z 1}^{3 / 2}}{\kappa h_{z 1}}\end{array}$ \\
\hline
\end{tabular}

流入条件、境界条件を表 2 に示す。

\section{表 2 境界条件}

$\kappa$ : カルマン定数 $(=0.4), u_{z-1}$ ：床面内仮想セルの風速， $u_{21}$ ：床面第 1 七ルの風速，

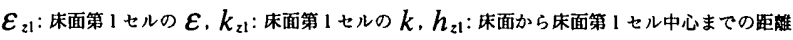

\section{6. モテル定数の確認}

各モデルの係数の最適值を、今回行った風洞実験データとの比較 から確認した。

Yamada, T. をべースとしたUno, I. et al. によるモデル（= Svensson, U. \& Häggkvist, K.) で $C_{p l \varepsilon}$ を変化させた場合の平均風 速及び乱流エネルギーの計算結果を図 7、8に示す。Uno, I. et al. のモデルでは、樹冠上部付近で実験との対応が悪い傾向が見られ た。 $\mathrm{x}=0.5 \mathrm{~h} \sim 0.75 \mathrm{~h}$ での平均風速は実験データにほぼ一致した。 乱流エネルギーは、実験データに比較して樹冠直後の $\mathrm{x}=0.5 \mathrm{~h}$ では

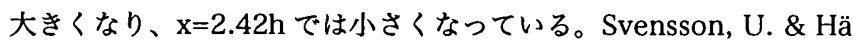
ggkvist, K. の求めた最適值 $C_{p l e}=1.95$ では、平均風速は $\mathrm{x}=1.0 \mathrm{~h}$ 以 降で実験データょりも風速回復までの距離が短く、乱流エネルギー のプロファイルも大きく異なり今回の実験データには一致しなかっ た。

Green, S.R. 及び Liu, J. et al. のモデルによる実験データとの比 較を図 9、10 に示す。Green, S.R.のモデルはUno, I. et al. に $L_{k}$ 、 


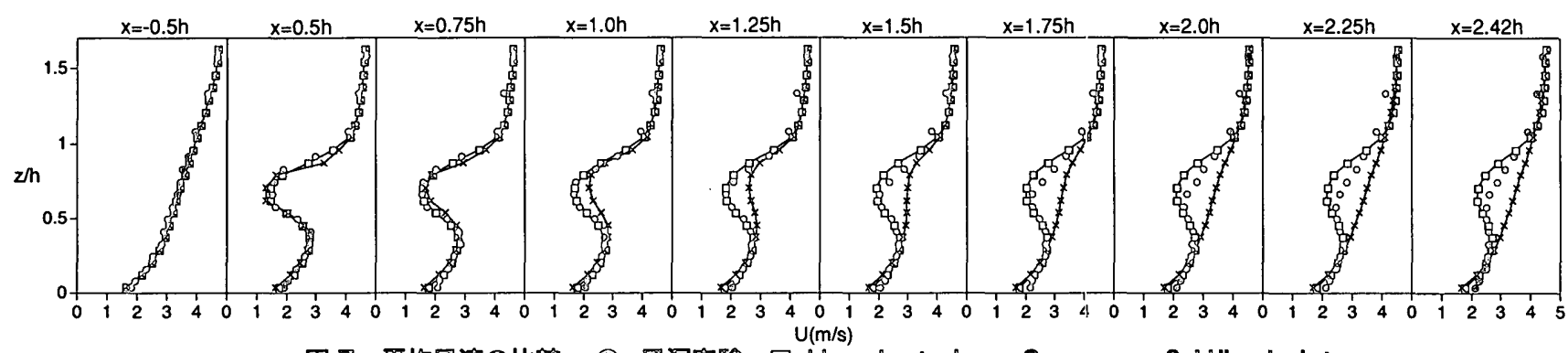

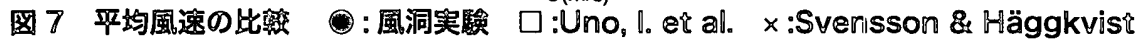

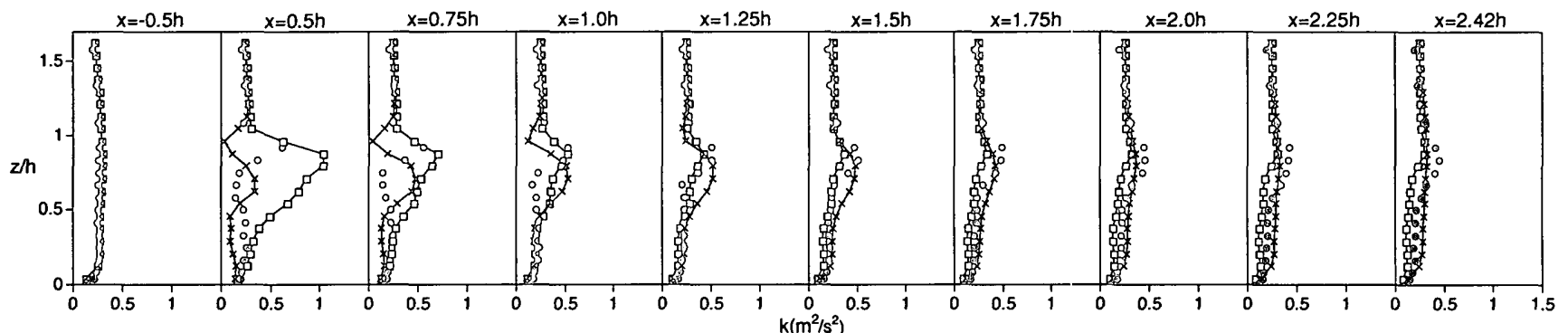

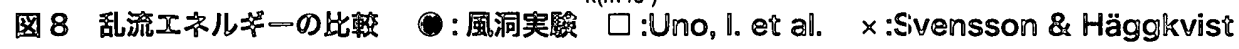

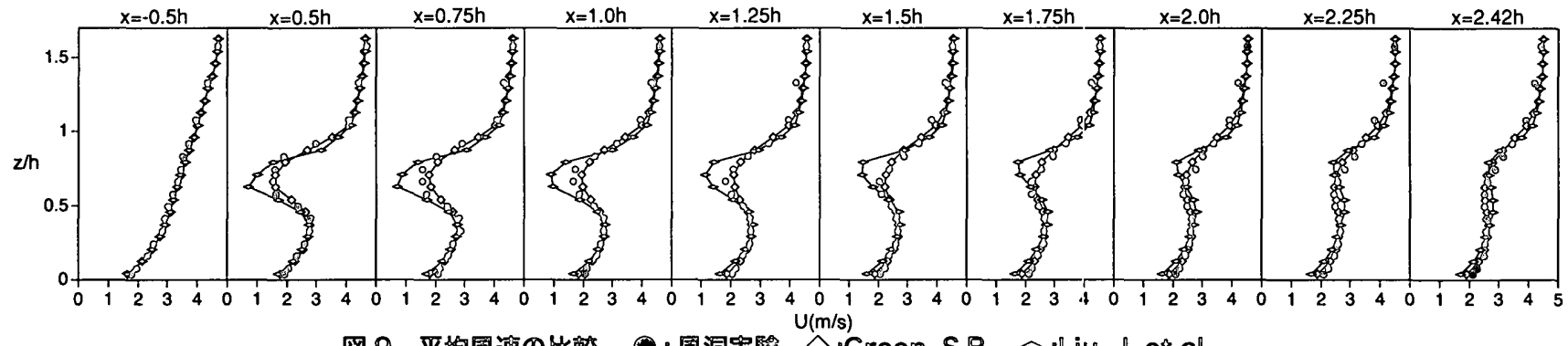

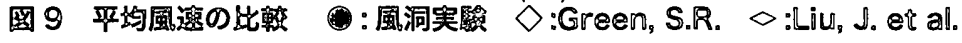

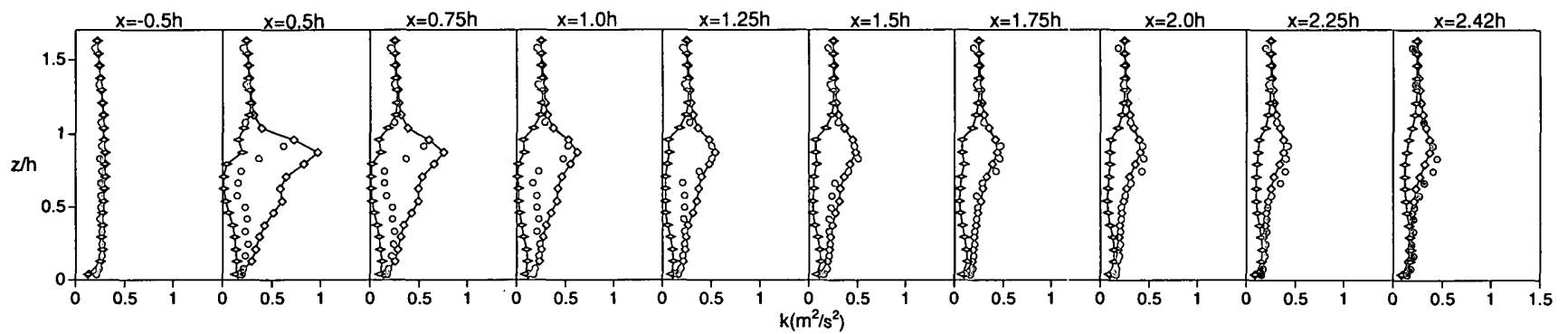

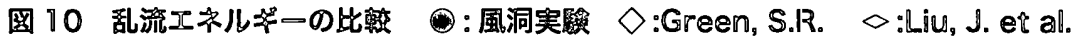

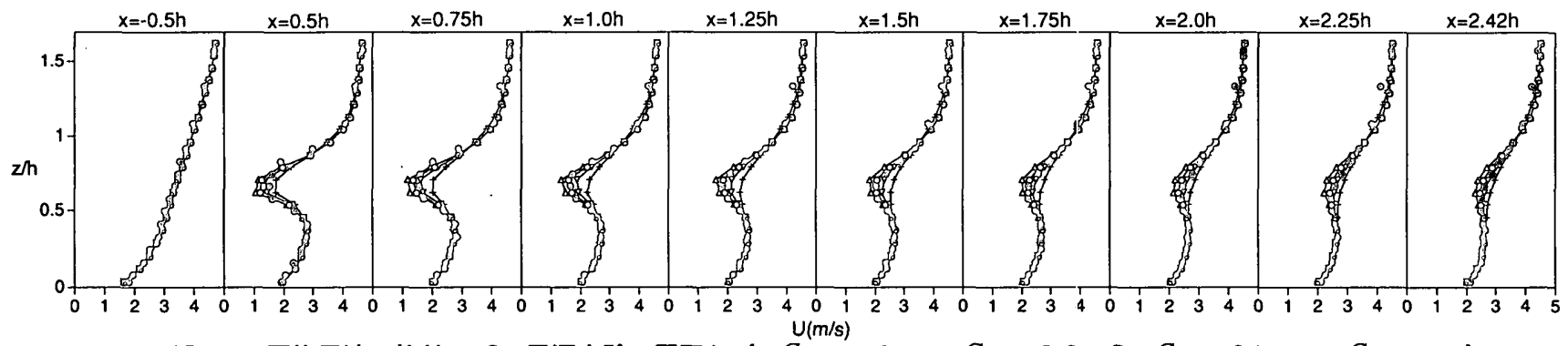

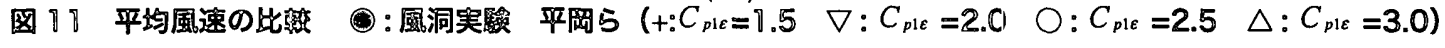

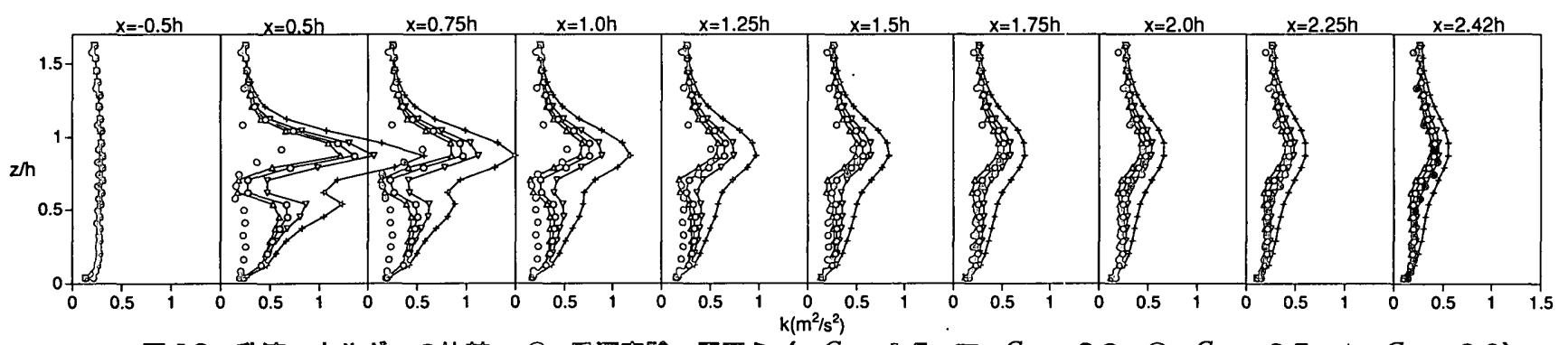

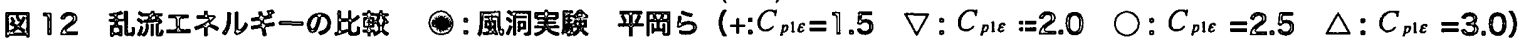




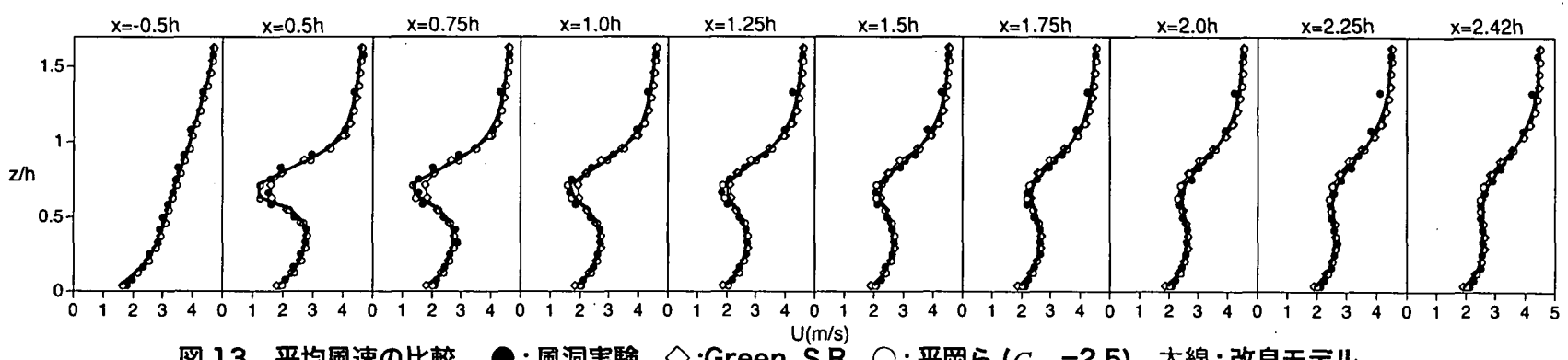

图 13 平均風速の比較

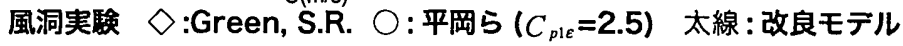

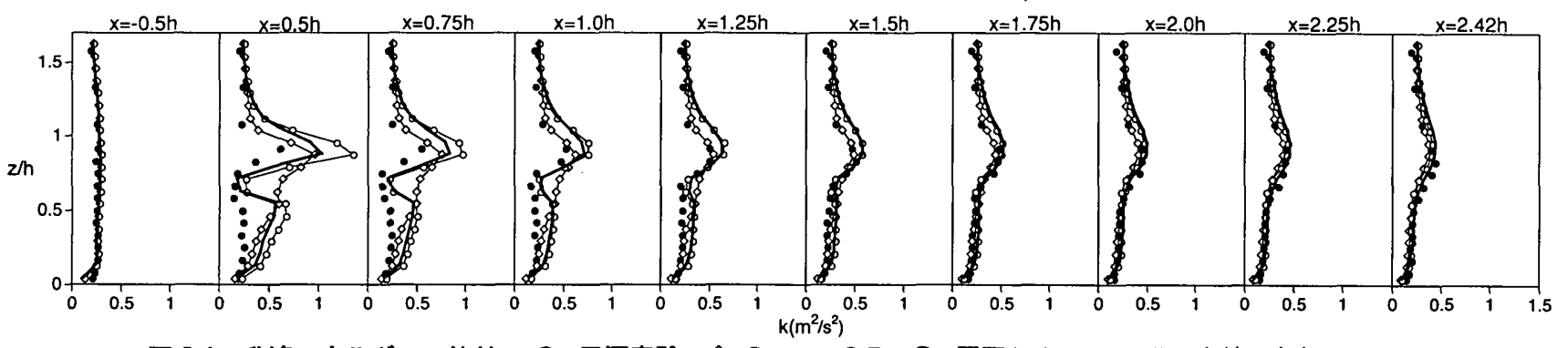

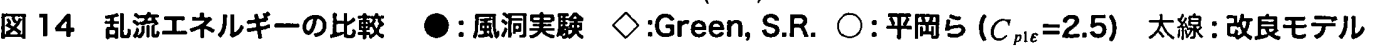

$L_{\varepsilon}$ を加えたものであるが、平均風速の分布はUno, I. et al. のモデ ルよりも実験に近い結果が得られた。乱流エネルギーの分布につい ても改善が見られ、実験データにより近づいた結果となった。しか し、Liu, J. et al.の行った $C_{p 2 \varepsilon}$ の補正を与えると実験データとの対 応は極端に悪くなった。

平岡らのモデルの最適な $C_{p l \varepsilon}$ は、平岡らの検討 ${ }^{9)}$ では植物群落の 場合 $0.8 \sim 1.2$ 程度、建物群の場合 10 程度と報告されている。平 岡らのモデルについて、 $C_{p l \varepsilon}$ の值を変化させて実験値との対応を確 認した。 $C_{r}$ は 1.0 とした。計算結果を図 $11 、 12$ に示す。図 11 を 見ると $C_{p I E}=1.5$ 程度では十分な風速隇少が見られなかったが 2.0 を超えると 3.0 まで実験デー夕にほぼ一致した。また、図 12 の の値も $C_{p l \varepsilon}=1.5$ の場合のみ極端に大きいが、2.0〜 3.0 では安定し て変化している。今回の実験データとの比較では、 $C_{p l e}=2.5$ 程度が 最適値となった。平岡らのモデルによる $k$ の分布の特徵として、樹 冠上下端の高さでは過大となるが、樹冠部分の高さに相当する 0.6 〜 $0.8 \mathrm{~h}$ 付近では他のモデルで見られた過大評価が抑えらた結果と なった。

\section{7. モデルの比較結果}

今回の検討では、Green, S.R.のモデルと平岡らのモデルが実験 データに良く一致した。Uno, I. et al. のモデルは平均流について は十分な結果が得られたが、 $\mathrm{x}=1.5 \mathrm{~h}$ 以降の高さ $\mathrm{z} / \mathrm{h}=0.5 \sim 1.0$. 付 近で実験データとの差がやや大きい。Green, S.R.のモデルは $L_{k} 、 L_{\varepsilon}$ により樹冠部分での $k$ の過大評価も多少抑えることができた。Liu， J. et al.の行った補正は今回の実験データには不要であった。平岡 らのモデルの係数 $C_{p l \varepsilon}$ は $2.0 \sim 3.0$ の範囲で比較的安定して平均流 を求めることができた。

\section{8. 改良モテル}

乱流エネルギーの分布を精度良く求めるために、Green, S.R. の用いた（6）式の $L_{k}$ が有効であることが確認できた。これは、 Shaw, R.H. \& Seginer, I. ${ }^{19}$ によって示されたキャノピー内の乱れ
の収支のフレームワークの提案に基づいたものであり、樹冠内部 では葉の影響により低周波から高周波へのエネルギーカスケードの 過程が短絡され、結果として $k$ の散逸が促進されるものとして㬰験 デー夕を根拠に考え出されたものである。Green, S.R.はこの項が 樹冠内の $k$ の収支に対して重要であると判断して、Wilson, J.D. ${ }^{(0)}$ に従い $k$ の消散項として $L_{k}$ をモデル化した。

また、平岡らは独自の方法で $F_{\varepsilon}$ をデル化し、樹冠部分での $k$ の增大を押さえることに成功している。

これらの結果を踏まえ、ここで単独の樹木により適したモデルに ついて考える。 $k$ の式には樹冠の影響を表す項として（11）式の $F_{k}$ を与え、さらに Green, S.R. に従い $L_{k}$ を付加することによって樹 冠内の $k$ の収支を調節する。 $\varepsilon$ の式は（3）式の平岡らのモデル化 に従って $F_{\varepsilon}$ を定義する。 $C_{p l \varepsilon}=2.5$ として、以上をまとめると表 1 の改良モデルのように表される。これは、平岡らのモデルで $C_{r}$ を 1.0 として $L_{k}$ を付加したものに等しい。この改良モデルによる計 算結果を Green, S.R、平岡らのモデルによる結果とともに図 13、 14 に示す。この結果から平岡らの $k$ の式に $L_{k}$ を加えることにより $\mathrm{x}=0.5 \mathrm{~h}$ での $\mathrm{z} / \mathrm{h}=0.5$ および $\mathrm{z} / \mathrm{h}=1.0$ 付近の樹冠上下端高さに見ら れる $k$ の增大が Green, S.R. 程度にまで抑えられ、平均流の分布も 実験值に一致することが確認できる。平岡らのモデルにおいてもこ の項は有効であり、この改良モデルによる結果が今回最も精度の良 いものとなった。

\section{9. おわりに}

樹冠内部の乱れの収支は非常に微妙なバランスの上に成り立って いると考えられる。Svensson, U. \& Häggkvist, K. や Liu, J. et al. の既往の検討でも、それぞれUno, I. et al. や Green, S.R. と同様 のモデルを用いていながらも係数にばらつきが生じている。平岡 ${ }^{201}$ は4タイプの RANS 型乱流モデルに、ここで取り上げた様々な夕

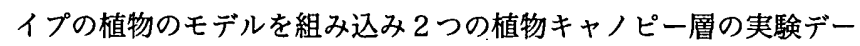
夕と比較しているが、その1次元計算でも実験データとの組み合わ せによって最適となる係数の值が異なることが報告されている。 
今回の検討により単独樹木に対する様々な植物キャノピー乱流モ デルの有効性や限界を示した。しかし、それらのモデル定数の普遍 的な有効範囲を確定するには不十分であり、さらなる検討を必要と する。今回得られた知見を以下にまとめる。

(a) 様々な植物キャノピー乱流モデルを用いて風洞実験データとの 比較により単独樹木への適用性について確認した。その結果、 平均流に関してはUno, I. et al.、Green, S.R.、および平岡らの モデルが実験データに比較的良く一致した。

(b)Green, S.R. のモデルは $L_{k} 、 L_{\varepsilon}$ を付加することによりUno, I. et al.よりも実験とよく一致した。

(c) 平岡らのモデルの場合、 $\varepsilon$ 式の $F_{\varepsilon}$ のモデル化が他と異なるが、 $C_{p l \varepsilon}$ にある程度の大きさ（今回の検討では 2.0 以上）を与える ことにより比較的安定した結果が得られることを確認した。

(d) 平岡らのモデルに $L_{k}$ を付加した改良モデルにより、より精度を 高めることができることを示した。

尼枵

$x_{i}$ : 空間座標の 3 成分、 $U_{i}$ 蜑速の 3 成分、 $l$ : 乱れの長さスケール、 $k$ : 乱流エネ ルキー、 $\varepsilon$ : 乱流エネルキー消散率、 $P$ : 圧力、 $\rho$ : 密度、 $\nu_{t}$ : 渦動粘性係数、 $L$ : 萧 によろ乱れの特徴长さスケール、 $a$ : 葉面䅞密度

\section{迢整立解}

1) 大橋征幹：植物キャノピー乱流モデルの改良，日本建築学会大会学術譄演梗概集 (D-2), pp.653-654, 2002.8

2）勝田高司，村上周三，杉山伸一，上原清：防風林（垣）の性能に関する風洞実験， 日本建築学会大会学術講演梗概集 (計画系), pp.185-186, 1973.10

3) 出口清孝，村上周三，高橋岳夫：実物樹木の防風効果に関する風洞实験（その1） 単体並ひに樹本列の防風効果について, 日本建築学会関東支部研究報告集（計画 系) , pp.21-24, 1984.7

4) 出口清孝，村上周三，高橋岳夫：実物樹木の防風効果心関する風洞实験（その 2) 高木と低木の組合わせ植栽の防風効果と樹木に加わる風在力について, 日本建築 学会関東支部研究報告集（計画系），pp.25-28, 1984.7

5) Wilson, N.R. and Shaw, R.H. : A Higher Order Closure Model for Canopy Flow, J. Appl. Meteorol., Vol.16, pp.1197-1205, 1977.11
6) Raupach, M. R. and Shaw, R. H. : An Averaging Procedure for Flow within Vegetation Canopies, Boundary-layer Meteorol., Vol.22, pp.79-90, 1982

7) Yamada, T. : A Numericil Model Study of Turbulence Airflow in and above a Forest Canopy, J. Meteorol, Soc. Japan, Vol.60, pp.439-454, 1982.2

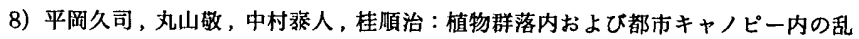
流モデルに関する研究（をのの1) 乱流モデルの作成, 日本建築学会計画系論文報 告雀, No.406, pp. I-9, 1989.12

9）平岡久司, 丸山敬, 中村筷人, 桂順治 : 植物群落内およぴ都市キャノピー内の乱 流モデルに関する研究（その2）実験データとの比較によるモデルの検証, 日本 建築学会計画系論文報告集, No.416,pp.1-8, 1990.10

10) Show, R.H., den Hartog, G., King, K.M. and Thurtell, G.W. : Measurements of Mean Wind Flow and Three-dimensional Turbulence Intensity within a mature Corn Canopy, A|jric. Meteorol., Vol.13, pp.419-425, 1974

11) Wilson, J.D. : A Second-order Closure Model for Flow through Vegetation, Boundary-Layer Meteorol., Vol.42, pp.371-392, 1988

12) Uno, I., Ueda, H. and Wakamatsu, S. : Numerical Modeling of the Nocturnal Urban Boundary Layer, Boundary-Layer Meteorol., Vol.49, pp.77-98, 1989

13) Svensson, U. \& Häggkvist, K. : A Two-equation Turbulence Model for Canopy Flows, J. Wind Eng. Ind. Aerodyn., Vol.35, pp.201-211, 1990

I4) Green, S.R. : Modeling Turbulent Air Flow in a Stand of Widely-spaced Trees., PHOENICS J. Comp. Fluid Dyn, and Applic., Vol.5, No.3, pp.294-312, 1992.7

15) Liu, J., Chen, J.M., Black, T.A. and Novak, M.D. : E- $\varepsilon$ Modeling of Turbulent Air Flow Downwind of a Model Forest Edge, Boundary-Layer Meteorol., Vol.77, pp.21.-44, 1996

16）村上周三，加藤信介，B.E. ロンダー, 鉿木啓泰 : 層流型クリーンルーム内の気流 性状・污染物桩散性状に関する研究（その6）床グレーチング通風抵抗を考成し た新しいk- $\varepsilon$ 型乱流モデルの提案, 生産研究, vol.40, No.1, pp.67-70, 1988.1

17）鉿木啓泰, 村上周三, 加藤伊介, B.E. ロンダー：層流型クリーンルーム内の気流 性状・污染物拻散性状に関する研究（その7）グレーチング压力損失の $\mathrm{k} 、 \varepsilon へ$ の影響を考慮した改良型 2 方程式モデル, 空気調和・衛生工学会学術講演会講演 論文集, pp.717-720, 1938.9

18) 大橋征幹, 神山健二, 成田健一：樹木の抵抗係数に関する風洞実験 その 2 抵 抗係数の算出と数值シミュレーション、日本建築学会学術講演梗概集 (D-2)， pp.523-524, 1999.9

19) Shaw, R.H. and Seginer, I. : The Dissipation of Turbulence in Plant Canopies, 7 th Symp. American Meteorol. Society on Turbulence and Diffusion, pp.200-203, 1985.11

20) 平岡久司 : 植物キャノビー乱流モデルの比較, 第 16 回数值流体力学シンポジウ ム講演論文集，B26-1, pp.1-9, 2002.12 